\title{
EU fossil fuel imports and changes after Ukrainian crisis
}

\author{
Peter Baláž ${ }^{1}$ (in memoriam), Stanislav Zábojník ${ }^{2, *}$, and Márius Hričovský3,* \\ ${ }^{1}$ Dpt. of International Trade, Faculty of Commerce, University of Economics in Bratislava, \\ Dolnozemská cesta 1, 85235 Bratislava, Slovakia \\ ${ }^{2}$ Dpt. of International Trade, Faculty of Commerce, University of Economics in Bratislava, \\ Dolnozemská cesta 1, 85235 Bratislava, Slovakia \\ ${ }^{3}$ SSE a. s., Pri Rajčianke 4B010 47 Žilina, Slovakia
}

\begin{abstract}
Russian-Ukrainian relations brought several challenges for the European energy security due to transportation corridors crossing the territory. Gas crisis in several CEE countries in early 2009 revealed brittle energy supplies stability of the net importers. The conflict in east Ukraine has brought new challenges for gas and oil shipments crossing the transport routes of Ukraine. Authors analyse transport corridors, presence of Nord Stream I and Nord Stream II projects as possible determinants of the importance of Ukrainian transport corridor and clarify exported volumes of fossil fuels from Russia to EU using the pipelines. The main objective of the article is to determine to what extent new transport routes for gas and oil by passing Ukraine will determine Slovak economy in the field of energy security as well as fiscal revenues. At the broader level, authors analyse potential effects for the whole EU in the field of energy security, transport costs but also $\mathrm{CO}_{2}$ footprint when using alternatives to pipelines. Article synthetises alternatives to Russian energy shipments, predominantly to CEE, and possible costs stemming from Ukrainian political changes. An added value of the article lies in analysis of the difference between commercial benefits of Russian supplies besides import dependence, regional effects and general energy policy goals fulfilment.
\end{abstract}

\section{Introduction}

The course of the globalization process so far has significantly changed the character of international competitiveness and the conditions under which it is achieved in countries and regions. This was reflected mainly in the speed and severity of changes in applied technological, economic, social and environmental factors, as well as in the increasing interdependence of individual countries, regions or localities. Since 2006, when the European Commission's Green Paper pointed to the significant dependence of EU competitiveness on the availability of energy resources, this link became the most important part of its energy policy. At the same time, ensuring secure energy supplies at affordable

\footnotetext{
*Corresponding author: stanislav.zabojnik@euba.sk, marius@hricovsky.eu
} 
prices is combined with an effort to reduce their import coverage. The ambition is a gradual diversification of used energy sources, their suppliers, as well as transport routes.

It turned out that although the EU's dependency is highest for imports of crude oil and its derivatives (around 90\%), the greatest risks were identified for imports of natural gas (70\%) [1]. Codified energy policy priorities include optimizing the energy mix; increasing the security of energy supply; developing energy infrastructure; diversification of energy sources and transport routes; maximizing the utilization of transmission networks and transit systems passing through Slovakia; improving energy efficiency and lowering energy intensity. Though, energy security, especially after harmful gas crisis in 2009, is a vital source of competitiveness, dependence on Russian fossil supplies are not negatively assessed especially after RES intensive implementation [1, 2]. Several authors stress an impact of the Ukrainian crisis on security, trade and particularly energy security [3]. Recently, energy security plays an important role in guaranteeing the national, political and economic security of any country [5]. Energy security at the SR level is considered as a pillar of Energy Policy as well as competitiveness and sustainability. Moreover, Slovakia together with Hungary have been meeting the Energy union targets the most successfully within V4 region [6]. This implication can also be defined at the level of the basic documents defining the EU Energy Union, but at least at CEE level these energy interests are more or less contradictory. The affordability of energy and hence the competitiveness of industry in recent years has been at the expense of political preferences and environmental aspects.

In connection with the creation and implementation of the key energy projects of the European Commission since 2014 (EU Energy Union officially presented in February 2015), the definition of energy security as such is being remodified. In the authors' opinion, more attention is paid to the "soft criteria" in the assessment of energy security, which until 2014 was perceived as supporting energy architecture that creates the conditions for increasing energy self-sufficiency, pro-export capacity in electricity, transparency and optimisation of the energy mix with low-carbon technologies and increasing energy efficiency in the interests of stability, the development of the national economy and the interests of consumers and their protection. Since 2015, however, the development of energy policies, key legislation as well as policy decisions has taken more account of the environmental aspects of the EU, as well as the transformed relationship between EU Member States and the Russian Federation. A strong feature of EU energy policy has been the increased emphasis on political and environmental aspects, which has its key implications for CEE countries, which are much more tied to Russian exports of energy carriers in infrastructure and trade.

The key change that brought turbulence to energy relations between EU countries (including CEE) was the annexation of Crimea and the introduction of anti-Russian sanctions along with the escalation of the situation in eastern Ukraine. The second major factor was the transition of the German economy to the Energiewende model, which is based on massive use of RES. The above-mentioned facts brought a fundamental change in the use of European energy infrastructure (especially the Bratstvo gas pipeline) in Eastern Europe. International transport corridors for oil transport remained intact (mainly the northern and southern branches of the Druzhba pipeline). However, fundamental changes have occurred with the construction of the Nord Stream I gas project, and in particular Nord Stream II, where Russian gas flows into the EU bypassing the CEE transport corridors. On the basis of the publicized German National Energy and Climate Plan, it will not be possible to compensate for higher instability in the energy system without a massive use of natural gas (Federal Ministry for Economic Affairs and Energy, 2019). This fundamental change in transmission routes (minority in resources) has its implications for CEE countries as well as in the economic performance of gas transmission system operators, the 
environment and, above all, overall energy security. Besides the positives [7], the negative perception of this project prevails in CEE countries, including Slovakia.

\section{Methodology}

The aim of the contribution is to identify, through statistical methods and in particular through qualitative research resources, the extent to which new gas routes (Nord Stream II) will affect (1) the intensity of the use of the original transit gas pipeline through Ukraine, (2) energy security of Slovakia and (3) fiscal revenues from its transportation to other countries. For the Slovak economy as a typical example of CEE - which is absolutely dependent on the success of its own exports and thus its level of competitiveness, this security also has the character of international political security and long-term economic stability.

\section{Results}

Regarding the strategic long-term position of natural gas in the EU energy sector, this is mainly related to the promotion of a new energy strategy (promoted mainly by Germany), which expects gradual phasing-out of nuclear sources, decay of coal power plants and significant drop in oil consumption (especially in automobile transport) and its replacement with electricity wherever technically possible. In Germany, nuclear power plants should be shut down by the end of 2022 and coal-fired by 2032. Obviously, such a coherent developmental trajectory will be a serious and costly encroachment on the existing energy policy of the whole cluster, with individual costs significantly differentiated. It will fundamentally translate into existing socio-political ties between suppliers of energy raw materials and their consumers. The deepening interdependence in this area between most EU Member States and Russia, to which have been set bilateral foreign trade flows, had for many years a far-reaching impact on the development of the industrial structure of both partners and to some extent also on production specialization and ultimately on their international economic position. Indisputably, there is a linkage between Russian gas strategy (and overall energy policy) and structural power of Russia [8]. According to some authors, since 2014, Russian policy has become more strategic, mixing different elements in pursuit of foreign policy objectives [9].

Russia delivers to the EU approximately $160-185$ billion $\mathrm{m}^{3}$, which is about $1 / 3$ of its total consumption and this volume should grow further, with $12 \%$ share of EU production in 2030 [10]. In particular, Germany's dependency, which counts on natural gas as a prospective energy substitute for nuclear and coal-fired power plants and its specialized industrial set-up for the supply of finished products to Russia, has proved to be the weakest link in the EU's unified approach to Russia. Despite several long-term recommendations [11], a diversity of the gas suppliers to the EU is still relatively low.

The need for a change in European geopolitics due to its high dependence on external gas supplies and the reduced ability to pay for their supplies of finished products has become more complicated in the context of the escalation of political tensions by the EU and Russia and the introduction of EU sanctions on trade, due to anti-sanctions. Subsequent annexation of the Crimea Peninsula has exacerbated the conflict. The result was the imposition of further protectionist measures against Russian exports by the EU and the US and further restricting trade relations by Russia. The instability of natural gas caused mainly due to Ukraine, but also the efforts of other countries on functioning on important natural gas routes, have brought widespread controversy over how to solve this complex problem.

Among the CEE countries, Russia plays a key role in the foreign trade of the Slovak Republic and especially in the foreign trade in energy carriers. SITC '27 'Mineral fuels, 
mineral oils and products of their distillation; bituminous substances; mineral ... "is at an extraordinary level. As seen from Table 1 which depends on a lower trend after 2014.

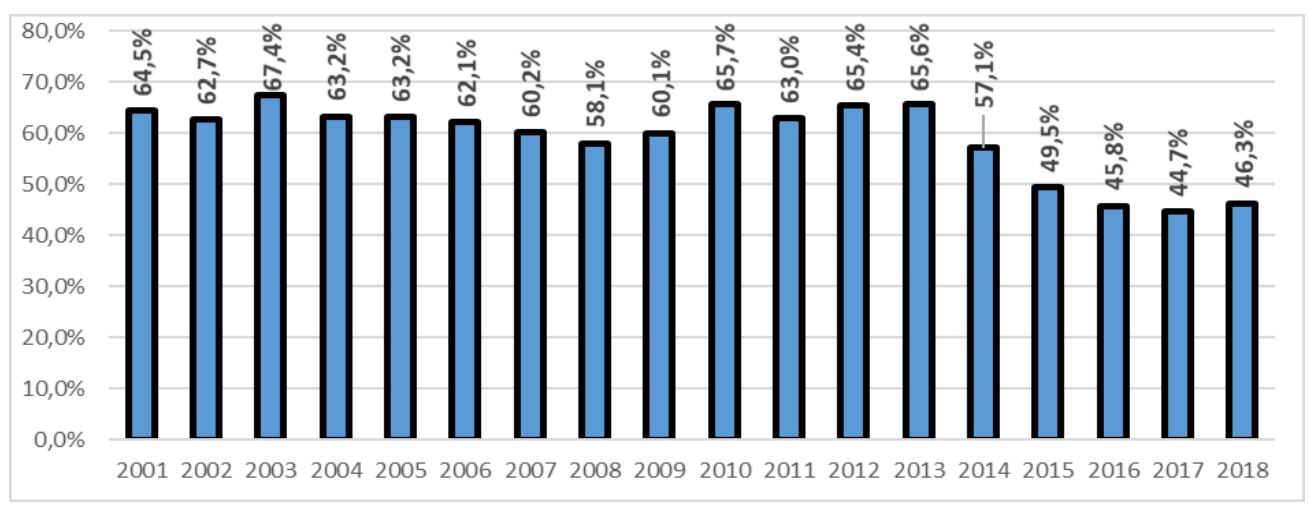

Fig. 1. Import dependence of CEE countries from Russia (commodity group '27) [12]

The effort to diversify the structure of suppliers and transport routes is strongly determined by existing pipelines and their capacity. These assets are generally already depreciated and have low operating costs. Until recently, the Bratstvo (Brotherhood) gas pipeline, which crosses Ukraine ${ }^{\dagger}$ and transport tariffs were an important source of the Ukrainian state budget, has a capacity of 155 billion $\mathrm{m}^{3}$ per year. In Europe, natural gas comes from Russia mainly through two pipelines, transit through Ukraine and Slovakia and the Jamal pipeline through Belarus and Poland. If the capacity of the transit route, which has never been fully utilized, is approx. 110 billion $\mathrm{m}^{3}$, the "Polish" route is able to transport approximately 30 billion $\mathrm{m}^{3}$. However, they are cumulatively used for only about $2 / 5$. With the existing consumption of this raw material in the EU -568 billion $\mathrm{m}^{3}$ in 2017 only these two existing routes, with very economically efficient operating cost, would cover a quarter of unitary consumption. Nordstream I or II has an annual capacity in each branch of 55 billion $\mathrm{m}^{3}$ natural gas and Yamal intersecting not only the transport corridor of Ukraine, but also Polish capacity 33 billion $\mathrm{m}^{3}$. An alternative to the Trans-Balkan gas pipeline is also contemplated, but capacity is limited to only $€ 20$ billion $\mathrm{m}^{3}$ per year and the commercial impact of Slovak energy companies is also very limited. However, a significant part of gas is also purchased by Slovak companies on international stock exchanges, in the case of Slovakia mainly in Baumgarten (CEGH) and German NCG.

We consider transport infrastructure to be an extremely important aspect of commercial advantage. The possibility of natural gas supply from the USA is coming to the fore in the media. This possibility undoubtedly exists, but with looking at the commercial advantage and thus the price competitiveness of European firms abroad, such a scenario only expands the possibilities for building energy security. For a realistic, commercially viable and sustainable solution to the import intensity of natural gas, this resource is unusable at breakeven prices above 35USD / bbl.

However, one cannot lose sight of the direct relationship between oil and gas prices (despite lower importance of oil-indexed long-term contracts that decreased gas prices for CEE, [13]) and the fact that when they reach a certain level there is a significant change in their share in the European energy consumption basket, which has both positive and negative impacts. Nevertheless, there has been changing, challenging the established trading principles of Russian gas in EU recently [14]. Unlike oil, which is supplied by

\footnotetext{
$\dagger$ Nevertheless, several authors suggest better energy security intensifying energy trade between Poland and Ukraine (Osieczko et al., 2018).
} 
several foreign producers and traded mostly on the stand-by market, in the case of natural gas its trade depends mainly on supplies from Russia, while the take-or-pay contracts used are of a long-term nature. Another important determinant of this link is the stationary gas pipeline network and the deployment of storage facilities, which does not allow for as much supply flexibility as oil. The industrial bases built in individual countries on the gas and oil pipeline routes were gradually adapted to their dislocation. However, there is no need to lose sight of the fact that transporting and storing natural gas is significantly more expensive than oil.

One of the new possibilities of reducing the import intensity of natural gas is the supply of its liquefied form (LNG) mainly from Qatar, Australia, Malaysia, Nigeria, etc., where modern regasification terminals were built. The explosion of its shale fracking production on the North American continent has also been accelerated by the construction of new terminals and sea routes for its transportation. The expansion of the LNG naval fleet is continuing dynamically (nearly 550 high-displacement ships were already available in 2018) as well as the construction of special tankers and bunkers. The introduction of new technologies is rapidly reducing production costs, which have so far been considerably higher than transport by pipelines. In 2017, one thousand meters of Russian gas cost 180190, with LNG over 250. The EU had 24 LNG terminals in 2018, but only one in Swinoujscie, Poland, with a capacity of 5-7 billion $\mathrm{m}^{3}$, is located in Central Europe. Therefore, it is not yet an alternative to Russian gas supplies. The total volume of LNG deliveries was only 80 billion $\mathrm{m}^{3}$ [15].

Table 1. Comparison of commercial advantage of gas sources for CEE region (USD/btu)

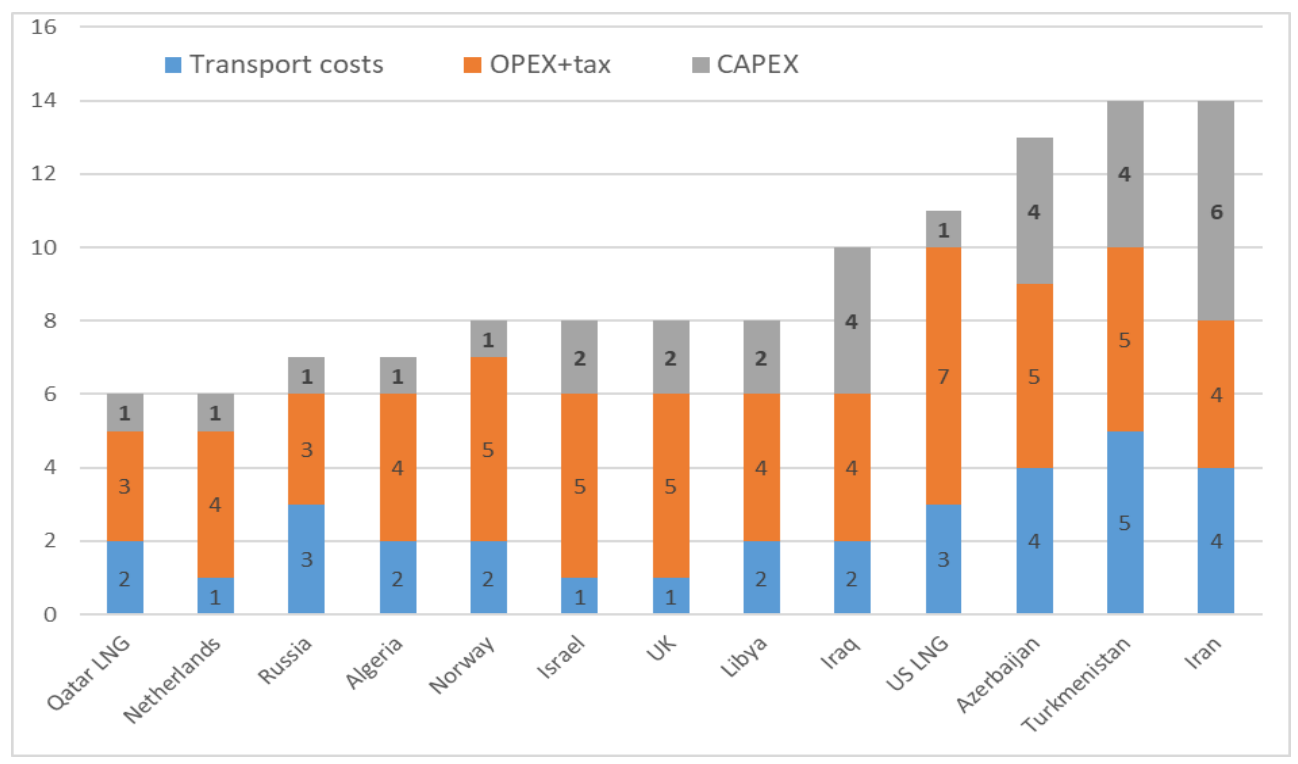

Apart from the obvious commercial disadvantage, it is important to note that the announced or real construction has the potential to significantly reduce contract prices from Gazprom for energy companies in EU Member States. This situation was demonstrated after the completion of the LNG terminal.

As the EU did not have alternative scenarios and the possibility of redirecting gas supplies from other countries was dependent on the implementation of huge projects, which take many years to build, the so-called project The North Stream (Nord Stream) bypasses all the risk regions and downstream of the neutral Baltic Sea, connecting the Russian 
terminal Vyborg with the German Greiswald $1225 \mathrm{~km}$ away. Its first branch was built during the period of relative political stability of EU-Russia relations (2012), with a cost of about $€ 6$ billion and a capacity of $€ 55$ billion, was connected to the European transmission network. Construction of the German hub meant that domestic firms have emerged from the position of paying for gas transit to the recipients of such charges, which also had a positive impact on government public finances. Germany covers half of its consumption by Russian gas, accounting for about a quarter of its energy mix.

Despite intense political tensions, a consortium of mainly German companies (Wintershall, Uniper, E.on, French Engie, British Shell and Austrian OMV), which will pay half the costs, have prepared the next stage of the Nord Stream II project, with similar capacity $€ 10$ billion). The other half is paid by Russian Gazprom. Construction has been much faster and should be operational by the end of 2019. The capacity of both pipelines will be cumulative at the level of the maximum capacity of the transit pipeline. Although construction costs are high, import will be cheaper as transit charges are eliminated. Also, the import operates directly, without the risk of shutdowns or supply disruptions for political reasons. This development, as the current production capacities of Russia are limited, will have a negative impact on the use of the transit transmission system, which flows into the SR only about 30 billion $\mathrm{m}^{3}$ of natural gas and will probably still fall. On the basis of official statistics of consumed and re-exported natural gas through the territory of the Slovak Republic we assume the maximum negative effect of -300 to -400 mil. $€$, which is the income limit in the semi-state gas carrier Eustream. A partial solution to this outage may be the construction of the Eastring gas pipeline, but this solution is promising in the next few years and only partially covers the failure of transported gas through the Ukrainian-Slovak corridor.

EU redefines new governance mechanisms and climate governance particularly in the "Winter package" [16]. The European Commission points out that the construction of the Nord stream II project contradicts the adopted European energy strategy to help reduce the use of fossil fuels, diversify their supply to several countries and thus reduce the risks. In negotiations within the European Union to eliminate the opposition of other Member States against Nordstream 2, Germany has sought to negotiate an agreement with Russia that even after the operation of Nord Stream II, transit through Ukraine will remain intact. Several economistst, especially from V4 countries have stressed harmful impact of the project in the region and labelled the project as politicising east-western energy relations [17] and some authors even ask to sanction the project [18]. In the case of the Slovak Republic, there are even more significant negatives resulting from the launch of this project mentioned above. The most important role covers expected alternative of Nord Stream II as an alternative to decreasing volume of the produced gas in the EU [10].

Efforts by the EU institutions to reduce their dependence on Russia's gas supply go to three areas. In the long term, through various subsidies, Turk Stream supports the construction of a transit route from Central Asia (with a capacity of 16 billion $\mathrm{m}^{3}$ ), the construction of new LNG import terminals and their involvement in global gas trade and acceleration of the new LNG terminal in Croatia on the island Krk with planned capacity 6 billion $\mathrm{m}^{3}$. Other possible alternative could be realized via Projects of Common Interest currently being constructed in Eastern Europe [20, 21]. However, all these planned projects will not have a major impact on the EU's existing dependence on natural gas imports from Russia in the coming years. This dependence should even increase, but it is questionable to what extent this growth will ensure transit through Ukraine and Slovakia. 


\section{Discussion}

These developments on the European gas market are currently not consistent with the Union's energy security strategy. The consensus of EU Member States is important for a successful solution, not only with regard to the natural gas market, but also to the final solution to the Ukrainian crisis and its conflict with Russia.

The problem is that the proposed solutions by the European Commission, but also the pressure of the US government on the European Union conflict with the economic interests of several European countries, especially Germany, to whom this trade provides considerable benefits. On the other hand, the blockade of Russian gas influence is supported by France, which covers only $12 \%$ of its consumption from Russia and also Poland, which ends the Gazprom contract in 2022 and quickly builds the northern branch linking it to Norwegian sites and has its own LNG terminal on the transit pipeline route, which may also cause serious financial losses to its closure.

Some European politicians argue that the opening of new gas hubs has internationalized gas trade and that Russia's "danger" has disappeared. The Russian strategy with the Nordstream II pipeline is to ensure a steady and uninterrupted gas offtake in the former satellite countries and thus to control them again.

Gazprom has the world's largest geologically proven reserves and (approx. 35 trillion $\mathrm{m}^{3}$ ) and its supplies will be cheaper for a long time than for LNG for mostly economic reasons. With domestic subsidized consumption approx. 230 billion. $\mathrm{m}^{3}$, for this company, the export of natural gas will be the main source of its profits enabling it to further invest in the expansion of its production.

\section{Conclusion}

As in 2005, no major changes in the structure of supply or transport corridors of Russian oil to the European market can be expected. However, we expect a different situation for natural gas. Russian natural gas is and will remain a very important import commodity for most of the EU member states, while the share of Russian oil and natural gas in total energy imports of CEE will stabilize or slightly decline. Its energy consumption will continue to grow significantly, primarily as a substitute for stable electricity as a substitute for electricity produced from nuclear and coal, as well as electric vehicle propulsion and thus oil substitution in western EU countries, but especially Germany.

Even in this situation, in order to comply with the set environmental standards and its own international competitiveness, it must focus on trading partners willing to respect the exchange of raw materials and take advantage of the existing comparative advantages of EU trade with Russia. These include the established system of oil and gas pipelines with the relevant infrastructure, which has its undisputed benefits in the priority area of energy policy - the environmental level. For many decades, the production structure of European firms has adapted to Russian demand, be it in terms of product range, capacity, or the required supply structure. Change of natural gas supplier eg. to Qatar or the US means making costly changes in this area or paying their cash supplies. And despite these major capital investments, there is no presumption that these alternative sources outstrip the commercial advantage of Russian gas and therefore have a positive impact on the price competitiveness of European producers. All of this would have a strong negative impact on the inside of EU Member States with the risk of political instability rising.

However, the idea of diversifying natural gas suppliers and ensuring EU energy security is logical, and communication of investment plans or smaller diversification projects is justified. In the case of several EU members, such projects (Swinoujscie, Klajpeda) put 
pressure on Gazprom and a real reduction in the contracted prices of this raw material. However, it would only achieve its systemic fulfilment if it were able to cover consumption from its own resources or to adapt its consumption to the available volumes. However, neither option is realistic in the short term. Also, for this reason, the fact that natural gas consumption creates space for the sale of finished products from the EU and this dependence also increases the overall economic and political stability of the region.

This paper is a part of a research project of the Ministry of Education, Family and Sports of the Slovak Republic VEGA (in the period 2017 - 2019) No. 1/0897/17: “The Importance of European Energy Union Project for Strategic Interests of This Grouping in the Context of the Enhancement of Competitiveness of the Slovak Republic.”

\section{References}

1. P. Baláž, A. Hamara, G. Sopková, Konkurencieschopnost' a jej význam v národnej ekonomike (Zmeny a výzvy vobdobí globálnej finančnej krízy). 1. ed. (Bratislava: Sprint dva, 2015)

2. P. Baláž, F. Margan, V. Ružeková, S. Zábojník, Energetická bezpečnost’ v období globalizácie a jej vplyv na konkurencieschopnost' EÚ. 1st ed. (Bratislava: Sprint dva, 2011).

3. J. J. Jaaskelainen et al. Finland's Dependence on Russian Energy-Mutually Beneficial Trade Relations or an Energy Security Threat? Sustainability, 10, (2018)

4. N. Ikani, Change and Continuity in the European Neighbourhood Policy: The Ukraine Crisis as a Critical Juncture. Geopolitics, 24, 20-50 (2019).

5. O. Chernyak, Trends of International Energy Security Risk Index in European Countries. Baltic Journal of European Studies, 8, 5-32 (2018).

6. A. Pach-Gurgul, M. Ulbrych, Progress of the V4 Countries towards the EU's Energy and Climate Targets in the Context of Energy Security Improvement (2019).

7. A. Barnes, CEPS. NORD STREAM 2-FRIEND OR ENEMY OF ENERGY SECURITY INEUROPE? Available on: https://www.ceps.eu/ceps-publications/nord-stream-2-friend-or-enemyenergy-security-europe/. (2017).

8. F. Proedrou, Russian Energy Policy and Structural Power in Europe. Europe.Asia Studies, 70, 75-89 (2018).

9. A. Matveeva, Russia's Power Projection after the Ukraine Crisis. Europe.Asia Studies, 70, 711-737 (2018).

10. P. Eser et al. Impact of Nord Stream 2 and LNG on gas trade and security of supply in the European gas network of 2030. Applied Energy, 238, 816-830 (2019).

11. M. Bilgin, Geopolitics of European natural gas demand: Supplies from Russia, Caspian and the Middle East. Energy Policy, 37, 4482-4492 (2009).

12. ITC database. UNCTAD and WTO database. Data available at: http://www.intracen.org/. (2019).

13. J. Wachsmuth, The end of long-term contracts? Gas price and market dynamics in Central and Eastern Europe. 14th Internmational Conference on the European Energy Market (EEM 17). IEEE (2017).

\footnotetext{
\$ The contracted gas prices for Poland were about 429 USD/1000 cubic meters though UK contracted Russian gas for 285 USD/1000 cubic meters. [19]
} 
14. J. S. Loe, Clash of Realities: Gazprom's Reasoning on the EU Gas Trade. Europe-Asia Studies, 71, 1122-1139 (2019)

15. Eurostat database. Energy statistics - quantities. (2019).

16. M. Ringel, M. Knodt, The governance of the European Energy Union: Efficiency, effectiveness and acceptance of the Winter Package 2016. Energy Policy, 112, 209-220 (2018).

17. R. Gotz, Nord Stream 2 The politicised pipeline (BWV-BERLINER WISSENSCHAFTS-VERLAG, 2019)

18. N. Snow, US sanctions necessary to stop Nord Stream 2 pipeline, speakers say. OIL \& GAS JOURNAL, 117, 30-31 (2019)

19. A. Semkou et al., Integrating Energy Markets in the Wider Europe: The Eastern Dimension. European Journal of Sustainable Development, 8, 101-113 (2019)

20. S. Tagliapietra, G. Zachmann, The Gazprom case: good timing or bad timing? Available on: http://bruegel.org/2015/04/the-gazprom-case-good-timing-or-badtiming/. (2015).

21. K. Osieczko et al., Comparison of chosen aspects of Energy Security Index for the natural gas sector in Poland and Ukraine. (DE GRUYTER POLAND, 2018) 